\title{
POVEZANOST MED VREMENOM IN OBISKOM IZBRANIH TURISTIČNIH TOČK V SLOVENIJI
}

\author{
Katja Vrtačnik Garbas \\ Oddelek za geografijo Filozofske fakultete Univerze v Ljubljani, Aškerčeva 2, \\ SI- 000 Ljubljana, Slovenija \\ e-mail: katja.vrtacnik@ff.uni-lj.si
}

Izvirni znanstveni članek

COBISS 1.01

\section{Izvleček}

Turizem je močno povezan $\mathrm{z}$ vremenom in s podnebjem ter $\mathrm{z}$ njegovim spreminjanjem. $\mathrm{V}$ tej raziskavi smo skušali na podlagi podatkov o dnevnem številu obiskovalcev izbranih različnih tipov turističnih točk v Sloveniji ugotoviti, kakšna je pravzaprav povezanost med posameznimi vremenskimi parametri in številom obiskovalcev. Njihovi odzivi pa nam dajejo vpogled v to, kako bi, preko spremenjenih vremenskih vzorcev, podnebne spremembe lahko vplivale na gibanje števila turistov in rekreativcev.

Ključne besede: vreme, podnebje, podnebne spremembe, turizem, rekreacija.

\section{THE CONNECTION BETWEEN THE WEATHER AND THE VISITS OF SELECTED TOURIST POINTS IN SLOVENIA}

\begin{abstract}
Tourism is strongly connected with the weather, the climate and its changes. In this research we used data on the daily number of visitors of selected different types of tourist points in Slovenia to find out what the connection between the weather and the number of visitors is actually like. Furthermore, their responses give us an insight into the possible influences that climate changes, through changed weather patterns, might have on the variation of the number of tourists and daily visitors.
\end{abstract}

Key words: weather, climate, climate changes, tourism, recreation. 


\section{UVOD}

Rekreacija in turizem se, $\mathrm{z}$ redkimi izjemami, odvijata na prostem, zaradi česar sta močno odvisna od vremenskih oziroma podnebnih razmer. Vreme, podnebje in turizem so tako na različne načine povezani med seboj. Vsi se zavedamo, kakšen je občutek, ko moramo zaradi slabega vremena odpovedati izlet ob koncu tedna, oziroma ko nam slabo vreme uniči težko pričakovane počitnice. Pomena vremena za turizem se močno zavedajo tudi zaposleni v tej gospodarski panogi, saj je njihov dobiček v primeru deževnih poletij in tako imenovanih zelenih zim brez snega, močno zmanjšan.

Podnebje, ki je definirano kot povprečno stanje v atmosferi, poleg številnih drugih faktorjev določa, če je posamezna oblika turizma na izbranem območju sploh mogoča ali ne. Dolgo časa je veljalo prepričanje, da je podnebje nekaj konstantnega, danes pa se zavedamo, da se podnebje zaradi različnih dejavnikov spreminja tako v času kot v prostoru (Abegg, 1996). V zadnjih desetletjih pa smo priča izrazitim spremembam podnebja, ki jim v veliki meri botruje človek. Različni družbeno-gospodarski kazalci tudi v prihodnje predvidevajo pomembno vlogo človeka pri spremenljivosti podnebja, zato se zdijo dokaj izrazite spremembe podnebja skoraj neizbežne (Houghton et al., 2001). Znanstveniki predvidevajo, da bodo podnebne spremembe verjetno vplivale tudi na turizem, ker pa dosedanje ugotovitve glede pričakovanih podnebnih sprememb vključujejo veliko mero negotovosti, so kakršnekoli napovedi glede vpliva podnebnih sprememb na turizem dejansko le teoretična predvidevanja, ki so skrajno negotova. Negotovost potencira tudi dejstvo, da na turistični promet poleg podnebja vplivajo še številni drugi dejavniki, kot so politično-gospodarska situacija, turistična propaganda, politika turizma v posamezni državi, turistična ponudba ter turistična infrastruktura, moda, mediji, posameznikova percepcija vremena ipd.

Vreme je med temi dejavniki še posebej izpostavljeno, saj vpliva na kratkoročno variabilnost števila turistov in rekreativcev (Brandenburg, 2001). Zato skušamo v tej raziskavi na izbranih primerih ugotoviti, kakšna je povezanost med vremenom, to je trenutnim stanjem $\mathrm{v}$ atmosferi, in obiskom turističnih točk, ki so zanimive za različne tipe turistov in rekreativcev. Njihovi odzivi na posamezne vremenske parametre pa nam hkrati dajejo vpogled v to, kako bi se turisti in rekreativci lahko odzivali na bodoče klimatske razmere. Poznavanje njihovih odzivov je namreč zelo pomembno, saj nam omogoča boljše prilagajanje ponudbe glede na zahteve in pričakovanja turistov.

\section{I.I. Raziskovalne domneve, cilji raziskave}

Abegg (1996) v svojem delu navaja nekaj avtorjev, ki so pri raziskovanju odnosa med vremenom in turizmomže uporabili različne statistične metodezaugotavljanjemere povezanosti. Godin in Matz (cv: Abegg, 1996) sta se npr. ukvarjala s tem, kakšna je povezanost med številom gostov in vremenskimi razmerami in prišla do ugotovitve, da med tema spremenljivkama ni nobene povezave, največje število gostov pa se ne glede na vreme pojavlja ob koncu tedna. Do podobnih rezultatov je prišel tudi McCulloch (cv: Abegg, 1996), ki je analiziral dnevni zaslužek od parkirnin na parkirišču v bližini mesta. Tudi on je ugotovil, da ima največji vpliv vikend, drugi največji vpliv pa so po podatkih njegove analize imele temperature zraka. Če 
to "popačenost" zaradi vpliva vikendov odpravimo, je pomen vremena po besedah Abegga lahko prikazati. Tako je Paul (cv: Abegg, 1996) npr. ugotovil, da imajo vremenski parametri na različne prostočasne aktivnosti različen vpliv: vreme tako zelo malo vpliva na odločitev za vožnjo s čolnom oziroma za piknik, medtem ko je plavanje zelo odvisno od vremena. Paul je tako prišel do ugotovitve, da vreme ne vpliva le na odločitev, ali se bo neka aktivnost izvajala ali ne, ampak tudi na privlačnost posamezne aktivnosti.

$\mathrm{V}$ naši raziskavi smo izhajali iz domneve, da vreme na izbrani turistični točki/kraju vpliva večinoma na dnevno variabilnost števila obiskovalcev, medtem ko je njegov vpliv na število počitnikarjev minimalen. Zajec (2004), ki se ukvarja z raziskavami turizma v okviru Slovenske turistične organizacije, je v pogovoru namreč ocenil, da vreme vpliva le na okrog $20 \%$ tistih turistov, ki počitnikujejo v izbranem kraju v organizaciji turističnih agencij, oziroma so si sami že vnaprej rezervirali prenočišče. Zaradi tega smo domnevali, da bomo dobili najboljše podatke o povezanosti med vremenom in turističnim obiskom ob uporabi dnevnih podatkov o številu obiskovalcev izbranih turističnih točk. Obisk le-teh namreč odraža število turistov, tem pa se (predvsem ob dela prostih dneh) pridružijo še dnevni obiskovalci. Ker Statistični urad Republike Slovenije dnevnih podatkov ne beleži, smo le-te pridobili od upraviteljev izbranih turističnih točk za obisk katerih je potrebno plačati vstopnino oziroma kupiti karto. V primeru Velike planine pa smo pridobili podatke o številu vpisov v planinsko knjigo. Ker zbiranje dnevnih podatkov ni zakonsko obvezujoče, je bilo le-te zelo težko dobiti, poleg tega pa obstajajo le podatki za relativno kratko časovno obdobje glavne sezone (izjema je Postojnska jama). Pri tem je potrebno dodati, da so se upoštevali le podatki za mesece, za katere so bili v obeh izbranih letih celomesečni podatki.

Temeljna domneva je bila, da je število obiskovalcev turističnih točk odvisno od vremena, vpliv vremena na različne prostočasne aktivnosti oziroma na obisk različnih tipov turističnih točk pa ni enak.

Poleg posameznih vremenskih parametrov nas je zanimala še kompleksna vrednost, ki vključuje različne vremenske parametre, to je fiziološki ekvivalent temperature. Ta termalni bioklimatski indeks ugodja osnovan na modelu človekove energetske bilance, prikazuje stopnjo temperaturne obremenitve, izračunati pa ga je mogoče z Matzarakisovim modelom Rayman (Matzarakis, 2000). V vseh izračunih se predpostavlja notranja produkcija toplote $80 \mathrm{~W}$ in stopnja rezistence prenosa toplote zaradi oblačil 0,9 .

Raziskovalne hipoteze so bile naslednje:

- H1: Ob prostih dnevih je obiskovalcev turističnih točk več ne glede na vreme (izleti ob koncu tedna in praznikih).

- H2: Ob višjih, a ne fiziološko preobremenjujočih, temperaturah je število obiskovalcev turističnih točk večje. Dokazano je namreč, da večina turistov iz najpomembnejših emitivnih trgov odhaja na počitnice v dežele, kjer so temperature višje kot v domačem kraju (Xaychaleune, 2003).

- H3: S povečano jasnostjo neba se število obiskovalcev turističnih točk na prostem povečuje.

- H4: Povečana oblačnost nima vpliva na število obiskovalcev znamenitosti v zaprtem prostoru (primer Postojnske jame), oziroma se s povečano oblačnostjo število obiskovalcev celo poveča.

H5: V primeru pojava megle je število smučarjev (primer Krvavca) manjše kot takrat, ko megle ni. 
H6: V primeru dežja je obiskovalcev turističnih točk, kjer je obisk povezan z lepim vremenom, manj.

H7: Na tistih turističnih točkah/krajih kjer so glavne turistične zanimivosti v zaprtem prostoru (npr. Postojna), pa dež nima velikega vpliva na število obiskovalcev.

H8: Z višanjem fiziološkega ekvivalenta temperature se število obiskovalcev povečuje, ob veliki, predvsem pa ob ekstremni toplotni obremenitvi, pa se število obiskovalcev zopet začne zmanjševati.

Cilj raziskave je prikazati, da obstaja povezanost med posameznimi vremenskimi parametri, fiziološkim ekvivalentom temperature in obiskom turističnih točk in na podlagi tega sklepati o vplivu vremena na različne oblike turizma in rekreacije. To pa bi nam v nadaljnjih raziskavah lahko služilo kot podlaga pri predvidevanju vpliva napovedanih podnebnih sprememb na turizem.

\section{I.2. Uporabljena metoda}

Uporabili smo podatke o vsakodnevnem vremenu (povprečne dnevne temperature, maksimalne dnevne temperature, dnevna višina padavin ter povprečna dnevna oblačnost, za računanje fiziološkega ekvivalenta temperature pa še povprečna dnevna relativna vlažnost in povprečna dnevna hitrost vetra; poleg tega smo v primeru smučišča na Krvavcu uporabili tudi podatek o megli, saj le-ta večkrat močno poslabša smučarske razmere ali jih celo onemogoči) na ustreznih referenčnih meteoroloških postajah (Velenje, Postojna, Lesce in Krvavec) v obdobjih za katere je bilo moč pridobiti podatke o dnevnem številu obiskovalcev Logarske doline, Postojnske jame, slapa Savice, smučišča Krvavec (tu smo upoštevali dnevno število prodanih kart, smučarjev pa je bilo zaradi sezonskih kart zagotovo več) in Velike planine.

Pri dnevnih povprečjih nismo uporabili podatkov o povprečnih vrednostih izračunanih na podlagi meritev ob $7 \mathrm{~h}, 14 \mathrm{~h}$ in $21 \mathrm{~h}$, ampak samo na podlagi meritev ob $7 \mathrm{~h}$ in $14 \mathrm{~h}$. Za to povprečje smo se odločili zato, ker jutranje stanje v veliki meri vpliva na izbiro potovanja oziroma aktivnosti, medtem ko popoldanska vrednost predstavlja vremensko stanje v času, ko so turisti in rekreativci najbolj aktivni. Večerno stanje pa dejansko nima več bistvenega vpliva na aktivnosti obiskovalcev.

Za ugotavljanje povezanosti med vremenskimi parametri in številom obiskovalcev posameznih turističnih točk smo podatke o dnevih, vremenskih parametrih in fiziološkem ekvivalentu temperature razdelili v razrede, zatem pa s pomočjo opisne statistike skušali prikazati, kakšna je frekvenčna porazdelitev števila obiskovalcev izbranih turističnih točk po posameznih razredih. Na podlagi tega pa smo poskušali ugotavljati, če vzorci kažejo kakšne pravilnosti v pojavljanju števila obiskovalcev izbranih turističnih točk glede na posamezne vremenske parametre.

Spremenljivke smo razdelili v razrede po naslednjih kriterijih:

\section{Dan v tednu}

To spremenljivko smo razdelili v dva razreda: delovni dan in prosti dan (sobota, nedelja, prazniki). 


\section{Temperature}

Za določanje tipov temperature smo uporabili Wakoniggovo klasifikacijo (cv: Brandenburg, 2001):

Tabela1: Tipi dnevne temperature po Wakoniggu

Table 1: Types of daily temperature according to Wakonigg

\begin{tabular}{|l|c|}
\hline \multicolumn{1}{|c|}{ Dnevne temperature } & Temperaturni tip \\
\hline $\mathrm{T} \max \geq 30^{\circ} \mathrm{C}$ in $\mathrm{T}$ povp $\geq 22^{\circ} \mathrm{C}$ & vroče \\
\hline $\mathrm{T} \max \geq 25^{\circ} \mathrm{C}$ in $\mathrm{T}$ povp $\geq 18^{\circ} \mathrm{C}$ & toplo \\
\hline $\mathrm{T} \max <25^{\circ} \mathrm{C}$ in $\mathrm{T}$ povp $\geq 12^{\circ} \mathrm{C}$ & zmerno toplo \\
\hline $\mathrm{T}$ povp od $5^{\circ} \mathrm{C}$ do $11,9^{\circ} \mathrm{C}$ & zmerno hladno \\
\hline $\mathrm{T}$ povp $<5^{\circ} \mathrm{C}$ & hladno \\
\hline $\mathrm{T} \max <0^{\circ} \mathrm{C}$ & mrzlo \\
\hline $\mathrm{T} \max \leq-10^{\circ} \mathrm{C}$ & zelo mrzlo \\
\hline
\end{tabular}

\section{Padavine}

Glede na višino padavin smo dneve razdelili na padavinske in suhe. Meja med obema kategorijama je bil $1 \mathrm{~mm}$ padavin (cv: Brandenburg, 2001):

\section{Tabela 2: Tipi padavin po Wakoniggu}

Table 2: Types of precipitation according to Wakonigg

\begin{tabular}{|c|c|}
\hline Višina padavin & Padavinski tip \\
\hline $0-1 \mathrm{~mm}$ & suh dan \\
\hline nad $1 \mathrm{~mm}$ & padavinski dan \\
\hline
\end{tabular}

\section{Oblačnost}

Pri klasifikaciji oblačnosti smo uporabili delitev po Auer et al. (cv: Brandenburg, 2001):

Tabela 3: Tipi oblačnosti po Wakoniggu

Table 3: Types of cloudiness according to Wakonigg

\begin{tabular}{|c|c|}
\hline $\begin{array}{c}\text { Oblačnost v desetinah } \\
\text { pokritega neba }\end{array}$ & Tip oblačnosti \\
\hline $0-1,9$ & jasno \\
\hline $2-4,9$ & lepo vreme \\
\hline $5-7,9$ & oblačno \\
\hline 8 in več & turoben dan \\
\hline
\end{tabular}




\section{Fiziološki ekvivalent temperature}

Fiziološki ekvivalent temperature je glede na termične zaznave klasificiran v naslednje tipe fiziološke toplotne obremenitve (cv: Brandenburg, 2001):

Tabela 4: Tipi fiziološke toplotne obremenitve po Höppe-ju

Table 4: Types of physiologic thermal stress according to Höppe

\begin{tabular}{|c|c|c|}
\hline $\begin{array}{c}\text { Fiziološki ekvivalent } \\
\text { temperature }\end{array}$ & Termični občutek & Fiziološka obremenitev \\
\hline do $4^{\circ} \mathrm{C}$ & zelo mrzlo & ekstremna obremenitev zaradi mraza \\
\hline $4,1-8^{\circ} \mathrm{C}$ & mrzlo & velika obremenitev zaradi mraza \\
\hline $8,1-13^{\circ} \mathrm{C}$ & hladno & zmerna obremenitev zaradi mraza \\
\hline $13,1-18^{\circ} \mathrm{C}$ & rahlo hladno & šibka obremenitev zaradi mraza \\
\hline $18,1-23^{\circ} \mathrm{C}$ & prijetno & toplotne obremenitve ni \\
\hline $23,1-29^{\circ} \mathrm{C}$ & rahlo toplo & šibka toplotna obremenitev \\
\hline $29,1-35^{\circ} \mathrm{C}$ & toplo & zmerna toplotna obremenitev \\
\hline $35,1-41^{\circ} \mathrm{C}$ & vroče & velika toplotna obremenitev \\
\hline 41,1 in več & zelo vroče & ekstremna toplotna obremenitev \\
\hline
\end{tabular}

\section{POVEZANOST MED VREMENOM IN OBISKOM IZBRANIH TURISTIČNIH TOČK V SLOVENIJI}

Naše ugotovitve so sledeče:

a) Kot vidimo iz grafov 1, 2, 3, 4 in 5 se je v obdobju junij-september 2003 število obiskovalcev vseh vzorčnih turističnih točk v izbranih mesecih gibalo v skladu z našimi pričakovanji. V vseh primerih je namreč število obiskovalcev ob dela prostih dneh večje kot med tednom. Do zunaj ležečih točk in ekstremnih vrednosti v grafih, ki prikazujejo število obiskovalcev v Logarski dolini, Postojnski jami in na Veliki planini je prišlo zaradi močno povečanega dnevnega števila obiskovalcev ob praznikih (v primeru Logarske doline močno izstopa 1. maj, v primeru Velike planine pa 15. avgust - Marijino vnebovzetje; na Veliki planini je namreč tudi cerkev Marije Snežne) oziroma v primeru organiziranih izletov, ki niso nujno vezani na dan v tednu ali na vreme.

b) Iz grafov 6, 7 in 8 je razvidno, da se je število obiskovalcev Logarske doline, slapa Savice in Postojnske jame z višanjem dnevnih temperatur povečevalo. Rahlo pozitivno povezanost je moč opaziti tudi na primeru števila obiskovalcev vpisanih v planinsko knjigo na Veliki planini, vendar pa je le-ta dosti manjša. V primeru Krvavca (graf 10) pa lahko ugotovimo, da temperature nimajo pomembnega vpliva na število smučarjev oz. da je njihov vpliv minimalen, medtem ko je vpliv drugih faktorjev (npr. zadostna količina snega, pokritost neba z oblaki itd) dosti močnejši. 
Graf 1: Frekvenčna porazdelitev števila obiskovalcev Logarske doline glede na dan v tednu (majseptember 2003,2004)

Figure 1: Frequency distribution of the number of visitors of the Logarska dolina valley according to the day of the week (May-September 2003, 2004)

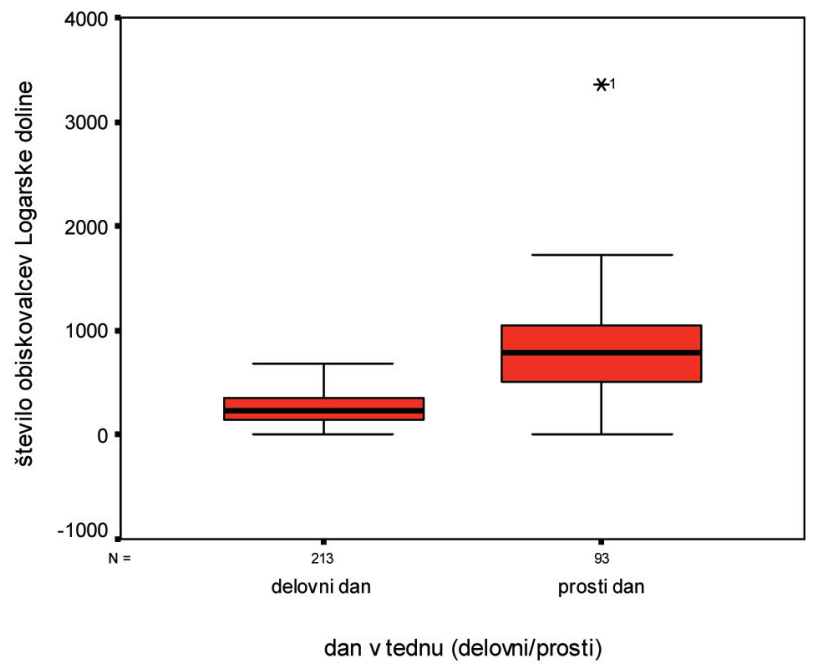

Graf 2: Frekvenčna porazdelitev števila obiskovalcev Postojnske jame glede na dan v tednu (januar-december 2002, 2003)

Figure 2: Frequency distribution of the number of visitors of the Postojnska jama cave according to the day of the week (January-December 2002, 2003)

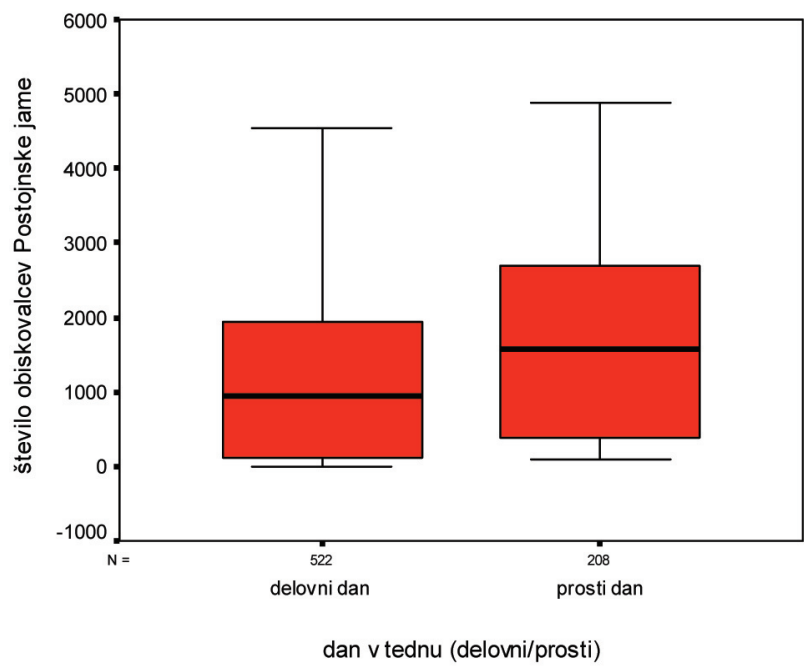


Graf 3: Frekvenčna porazdelitev števila obiskovalcev slapa Savice glede na dan v tednu (maj-julij 2002, 2003)

Figure 3: Frequency distribution of the number of visitors of the Savica waterfall according to the day of the week (May-July 2002, 2003)

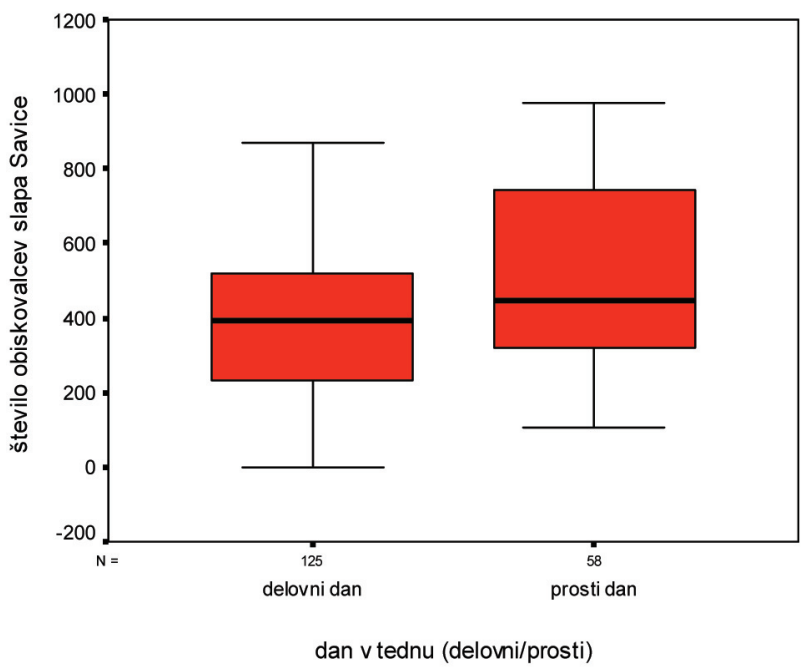

Graf 4: Frekvenčna porazdelitev števila prodanih smučarskih kart na Krvavcu glede na dan v tednu (januar-marec 2003, 2004)

Figure 4: Frequency distribution of the number of ski tickets sold on Krvavec according to the day of the week (January-March 2003, 2004)

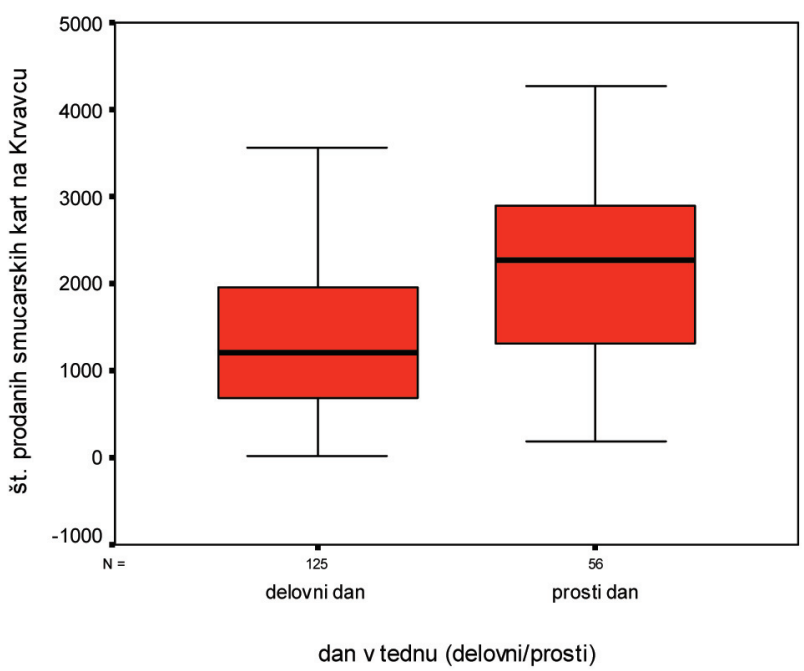


Graf 5: Frekvenčna porazdelitev števila obiskovalcev vpisanih v planinsko knjigo na Veliki planini glede na dan v tednu (junij-september 2002, 2003)

Figure 5: Frequency distribution of the number of visitors registered into the mountaineers' book on the Velika planina alp according to the day of the week (June-September 2002, 2003)

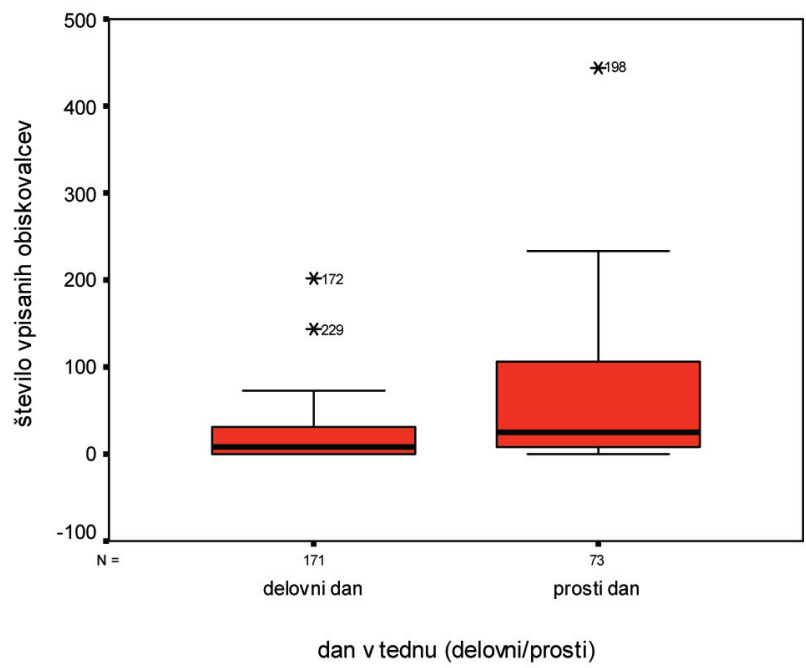

Graf 6: Frekvenčna porazdelitev števila obiskovalcev Logarske doline glede na tip temperature (maj-september 2003, 2004)

Figure 6: Frequency distribution of the number of visitors of the Logarska dolina valley according to the temperature type (May-September 2003, 2004)

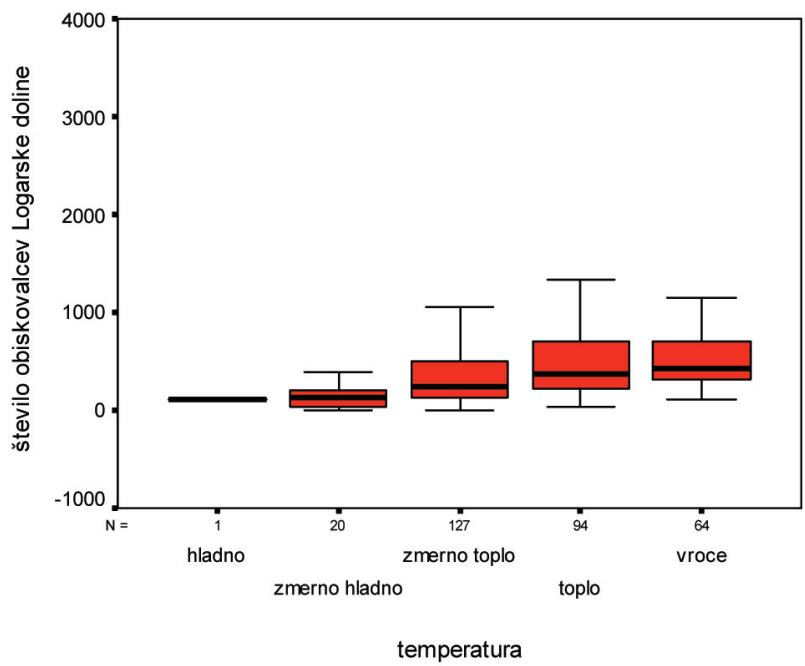


Graf 7: Frekvenčna porazdelitev števila obiskovalcev Postojnske jame glede na tip temperature (januar-december 2002, 2003)

Figure 7: Frequency distribution of the number of visitors of the Postojnska jama cave according to the temperature type (January-December 2002, 2003)

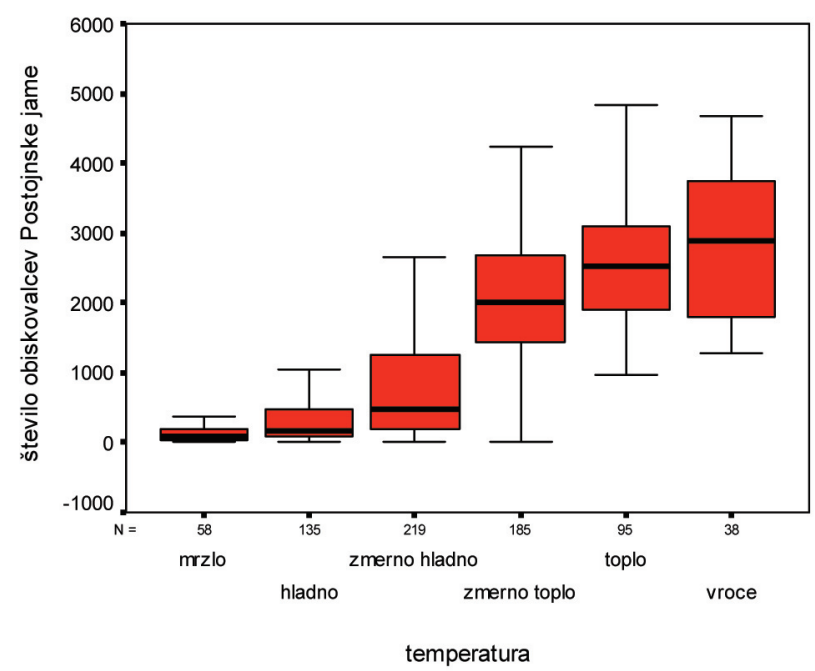

Graf 8: Frekvenčna porazdelitev števila obiskovalcev slapa Savice glede na tip temperature (majjulij 2002, 2003)

Figure 8: Frequency distribution of the number of visitors of the Savica waterfall according to the temperature type (May-July 2002, 2003)

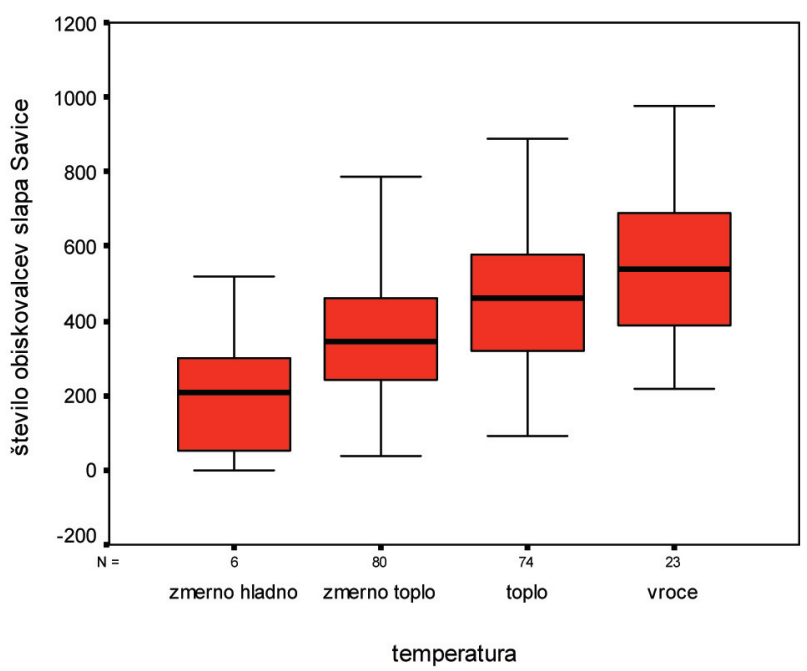


Graf 9: Frekvenčna porazdelitev števila obiskovalcev vpisanih v planinsko knjigo na Veliki planini (junij-september 2002, 2003)

Figure 9: Frequency distribution of the number of visitors registered into the mountaineers'book on the Velika planina alp (June-September 2002, 2003)

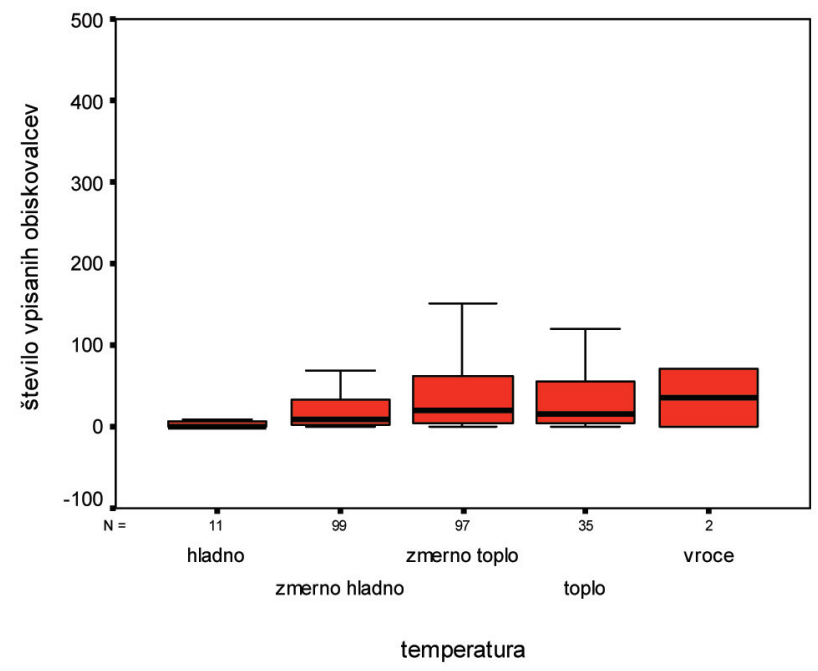

Graf 10: Frekvenčna porazdelitev števila prodanih smučarskih kart na Krvavcu glede na tip temperature (januar-marec 2003, 2004)

Figure 10: Frequency distribution of the number of ski tickets sold on Krvavec according to the temperature type (January-March 2003, 2004)

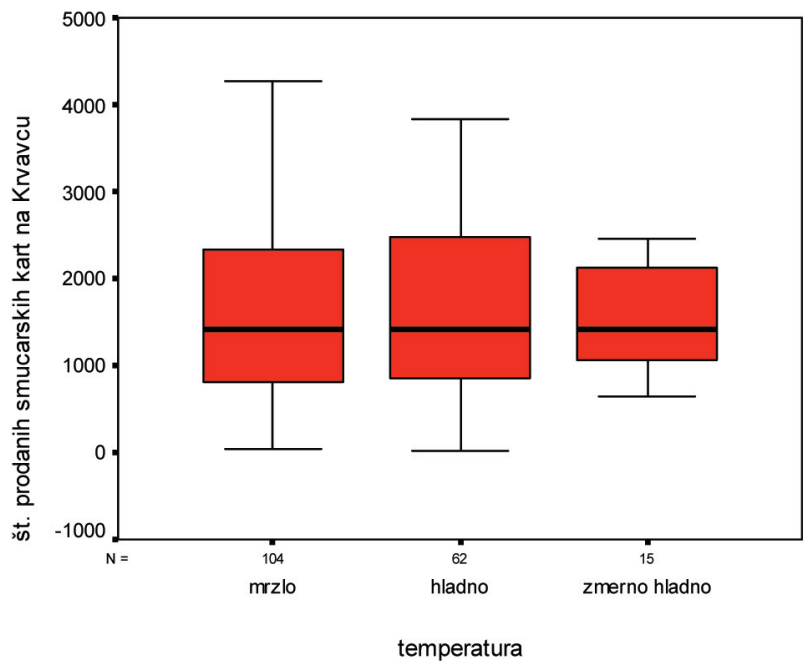


Pri trditvah o pozitivni povezanosti med dnevnimi temperaturami in številom obiskovalcev izbranih turističnih točk pa moramo upoštevati, da so bile dnevne temperature najvišje julija oziroma avgusta, ko je tudi višek sezone, poleg tega pa se v tem mesecu v Italiji, od koder izhaja kar 21,7 \% tujih turistov v Sloveniji (Statistični urad Republike Slovenije, 2006), začne 'feragosta'.

Tako je bilo avgusta 2002 (slap Savica) oziroma 2003 (Logarska dolina, Velika planina, Postojnska jama) število obiskovalcev vseh izbranih turističnih točk največje (graf 11).

Graf 11: Število obiskovalcev Logarske doline, Postojnske jame, število obiskovalcev vpisanih v planinsko knjigo na Veliki planini (maj-september 2003) in število obiskovalcev slapa Savice (majseptember 2002) po mesecih*

Figure 11: The number of visitors of the Logarska dolina valley, the Postojnska jama cave, the number of visitors registered in the mountaineers'book on the Velika planina alp (May-September 2003) and the number of visitors of the Savica waterfall (May-September 2002) by month*

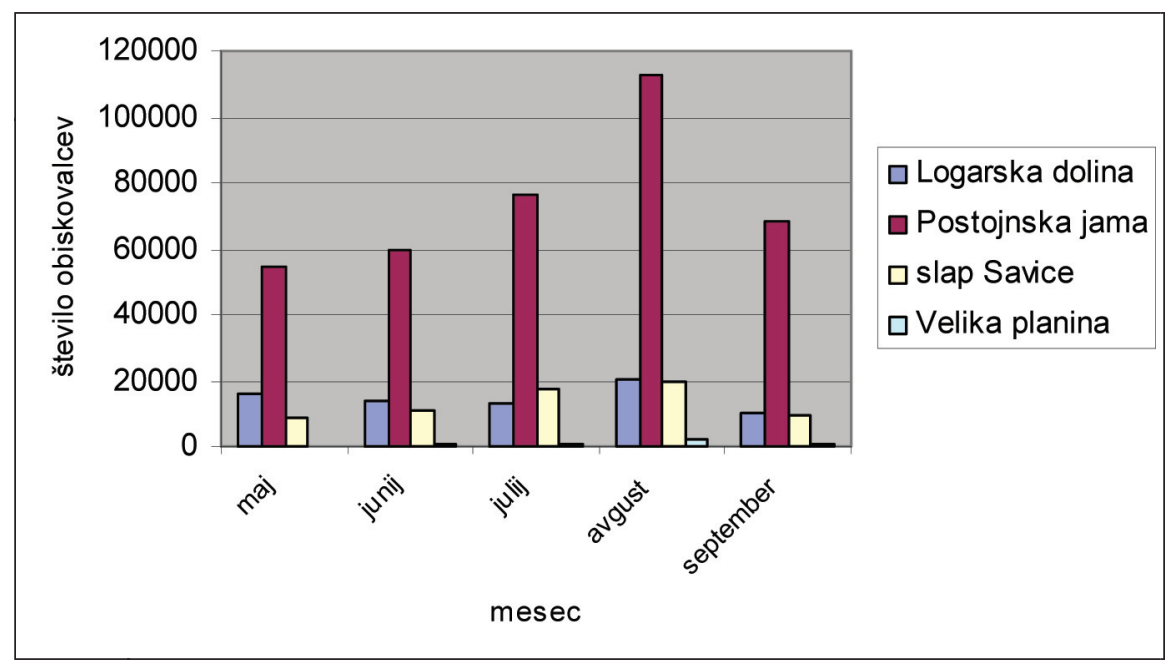

* Pri slapu Savici je prikazano število obiskovalcev leta 2002 zato, ker je avgusta 2003 na Komarči prišlo do obsežnega požara, zaradi katerega je bila sezona prekinjena.

To pomeni, da je načeloma število obiskovalcev turističnih točk oziroma turističnih krajev v Sloveniji ne glede na vreme julija in avgusta višje kot v ostalih mesecih. Izjema so seveda turistične točke/kraji, v katerih prevladuje zimsko-športna ponudba, zaradi česar imajo le-ti višek sezone pozimi (npr. Krvavec, Cerkno).

Nasprotno se je glavna sezona v večini turističnih točk/krajev v Sloveniji oblikovala julija in avgusta ravno zaradi najvišjih temperatur, tako da je težko trditi ali frekvenčna porazdelitev števila obiskovalcev izbranih turističnih točk odraža le vpliv sezonskosti, saj je le-ta prav tako povezana s temperaturami. 
Raziskovalci ki se ukvarjajo z gibanjem turističnega prometa v Evropi, pa so prišli do nasprotnih ugotovitev. Opazili so namreč, da se v primeru izredno vročih poletij turisti iz severnejših držav (npr. Britanskega otočja, Skandinavskega polotoka, Nizozemske, Nemčije itd.), ki predstavljajo najpomembnejše emitivne trge v Sredozemlju, pogosteje odločajo za počitnice doma. V primeru podnebnih sprememb, pa naj bi bil v poletni sezoni višek turističnega obiska junija in septembra, nižek pa julija in avgusta (Perry, 2003). Te teze na podlagi naših podatkov kljub ekstremno vročemu poletju 2003 ne bi mogli potrditi. Temperature pa zagotovo vplivajo na starostno strukturo gostov, saj visoke temperature delujejo na organizem obremenilno, še posebno na starejše ljudi in majhne otroke, zaradi česar se te skupine turistov že sedaj odločajo za počitnice v pred- in po- sezoni. To bi lahko dokazali, če bi primerjali podatke o večletnih povprečnih mesečnih temperaturah in starostni strukturi turistov. Le-te pa je izredno težko dobiti.

c) Tretjo hipotezo, ki pravi, da se s povečano jasnostjo neba število obiskovalcev turističnih točk povečuje, lahko brez kakršnihkoli zadržkov potrdimo na primeru Krvavca, kjer se je v izbranem obdobju število prodanih smučarskih kart oziroma smučarjev s povečevanjem oblačnosti izrazito zmanjševalo. Prav tako se je z večanjem oblačnosti zmanjševalo število obiskovalcev Logarske doline.

Graf 12: Frekvenčna porazdelitev števila prodanih smučarskih kart na Krvavcu glede na tip oblačnosti (januar-marec 2003, 2004)

Figure 12: Frequency distribution of the number of ski tickets sold on Krvavec according to the cloudiness type (January-March 2003, 2004)

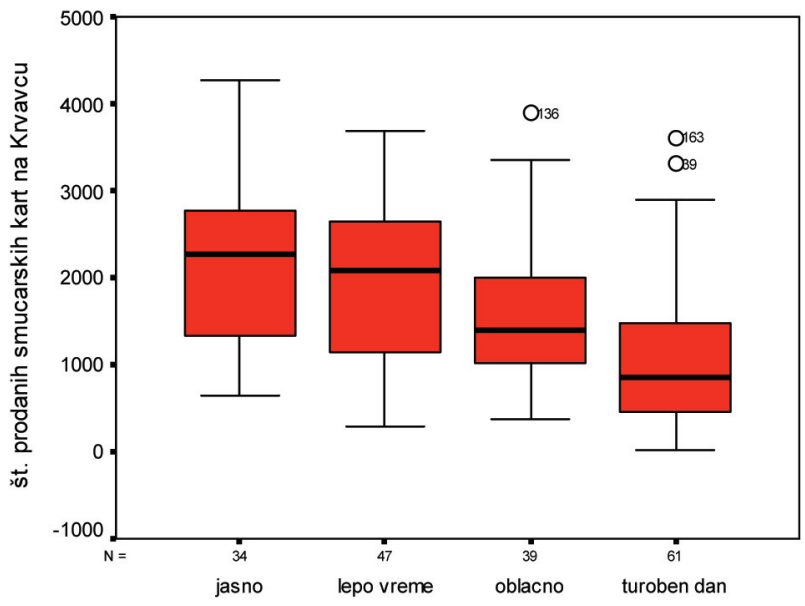

tip oblacnosti 
Graf 13: Frekvenčna porazdelitev števila obiskovalcev Logarske doline glede na tip oblačnosti (maj-september 2003, 2004)

Figure 13: Frequency distribution of the number of visitors of the Logarska dolina valley according to the cloudiness type (May-September 2003, 2004)

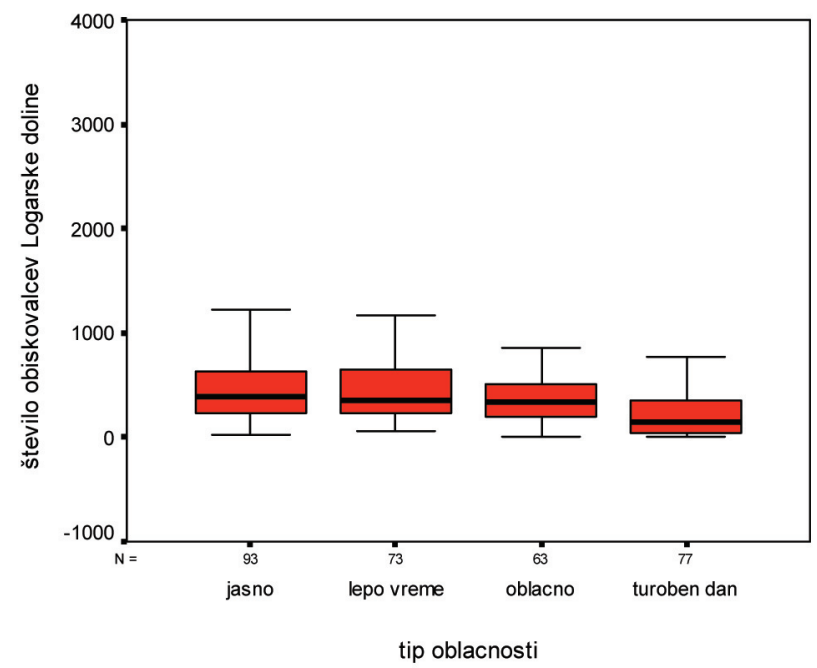

Graf 14: Frekvenčna porazdelitev števila obiskovalcev vpisanih v planinsko knjigo na Veliki planini glede na tip oblačnosti (junij-september 2002, 2003)

Figure 14: Frequency distribution of the number of visitors registered into the mountaineers' book on the Velika planina alp according to the cloudiness type (June-September 2002, 2003)

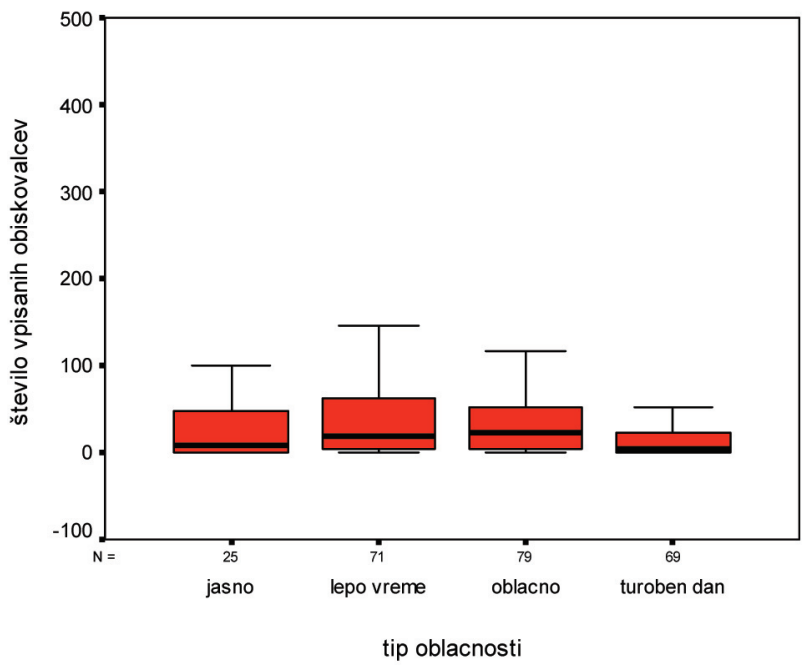


Kot je razvidno iz grafa 14 je bil vpliv oblačnosti na število obiskovalcev na Veliki planini manj očiten. Največ obiskovalcev je bilo namreč, ko je bilo vreme lepo, sledijo oblačni dnevi in šele zatem jasni dnevi. Bolj izrazit upad števila obiskovalcev je razviden le v primeru turobnih dni. Če odstranimo stolpec, ki predstavlja razporejanje števila obiskovalcev vpisanih v planinsko knjigo ob jasnem vremenu, opazimo, da se je s povečano oblačnostjo število obiskovalcev na Veliki planini, v skladu z našimi pričakovanji, zmanjševalo.

V primeru slapa Savice je prišlo do zanimive situacije. V izbranem obdobju je bilo namreč v povprečju število obiskovalcev največje takrat, ko je bilo oblačno, temu pa sledijo dnevi z jasnim in lepim vremenom. Nastalo sliko lahko verjetno razložimo kar s pregovorom, ki pravi, "da ima v Bohinju dež mlade", če pa že ni dežja, je pa vsaj nebo oblačno. Oblačnost pa, razen če je več kot 8 desetin neba pokritega z oblaki, na število obiskovalcev slapa Savice očitno nima negativnega vpliva.

Graf 15: Frekvenčna porazdelitev števila obiskovalcev slapa Savice glede na tip oblačnosti (junijseptember 2003)

Figure 15: Frequency distribution of the number of visitors of the Savica waterfall according to the cloudiness type (June-September 2003)

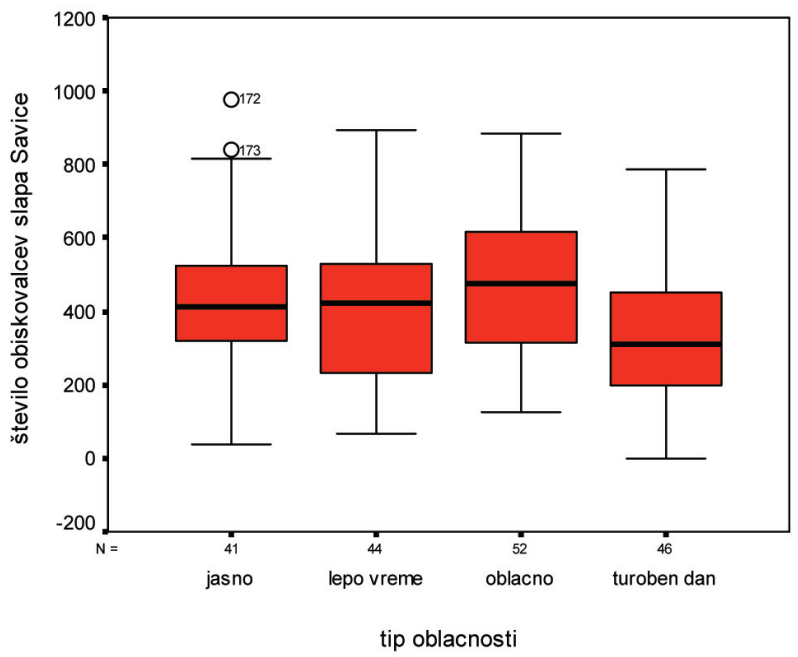

Rezultati o razporejanju števila obiskovalcev Postojnske jame glede na oblačnost pa so bili v nasprotju s četrto hipotezo. Iz grafa 16 namreč vidimo, da se je, če odstranimo stolpec, ki prikazuje jasne dneve, število obiskovalcev Postojnske jame s povečano oblačnostjo zmanjševalo.

Drugačen rezultat pa dobimo, če analiziramo le mesece, ki predstavljajo glavno sezono (maj-september). Iz grafa 17 namreč vidimo, da oblačnost dejansko nima negativnega vpliva na število obiskovalcev Postojnske jame, oziroma, da je bilo v izbranem obdobju v povprečju število obiskovalcev največje, ko je bilo več kot 8 desetin neba pokritega $\mathrm{z}$ oblaki (turoben dan). Ta rezultat pa je v skladu $\mathrm{z}$ našo hipotezo. 
Graf 16: Frekvenčna porazdelitev števila obiskovalcev Postojnske jame glede na tip oblačnosti (januar-december 2002, 2003)

Figure 16: Frequency distribution of the number of visitors of the Postojnska jama cave according to the cloudiness type (January-December 2002, 2003)

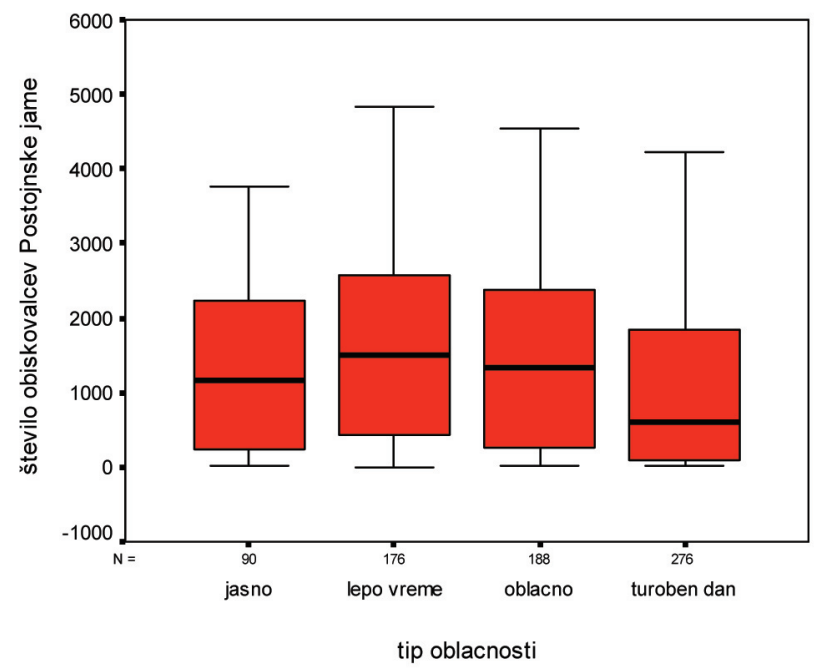

Graf 17: Frekvenčna porazdelitev števila obiskovalcev Postojnske jame glede na tip oblačnosti (maj-september 2002, 2003)

Figure 16: Frequency distribution of the number of visitors of the Postojnska jama cave according to the cloudiness type (May-September 2002, 2003)

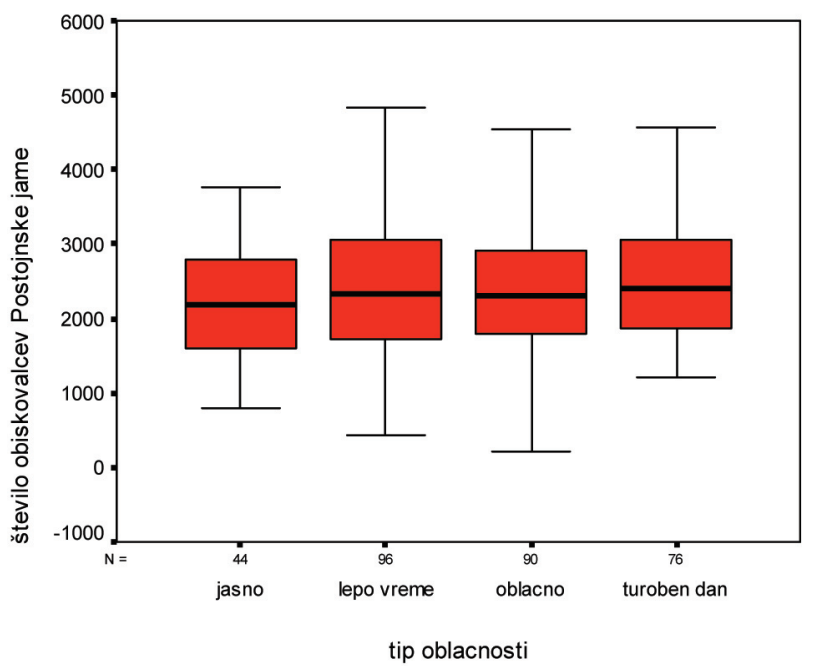


Pri raziskovanju vplivov oblačnosti na turiste in rekreativce se je potrebno zavedati, da je oblačnost že v osnovi precej subjektiven parameter, saj se opazuje in ne meri. Opozoriti je potrebno, da jasnost ne pomeni isto kot sončnost, ki je za turiste najbolj pomembna. Nebo je namreč lahko precej pokrito $\mathrm{z}$ visokimi oblaki, vendar skozi visoke oblake sonce še dokaj neovirano sije. Če je z oblaki prekrita južna polovica neba, severna pa jasna, ob deloma jasnem vremenu sonca sploh ne vidimo, če pa je razporeditev oblačnosti obrnjena, pa lahko ob enaki oblačnosti sonce ves dan prijetno sije. Izjemni primeri so lahko celo taki, da ob pretežno oblačnem vremenu sonce več ali manj ves čas sije skozi redke jasnine, ali pa da ob pretežno jasnem vremenu posamezen oblak potuje preko neba ravno tako, da zakriva sonce (Rakovec, Vrhovec, 1998, str. 64).

e) V primeru smučišča na Krvavcu se nam je zdelo smiselno raziskati še variiranje števila prodanih kart v odvisnosti od pojava megle.

V okviru meteoroloških opazovanj je pojav megle definiran tako, da je tedaj horizontalna vidnost (razdalja do katere ločimo temne predmete med seboj) v vsaj eni smeri manjša od 1 km (Rakovec, Vrhovec, 1998).

Iz grafa 18 je očitno, da naša hipoteza, ki pravi, da je v primeru megle, ki močno ovira smučanje, število smučarjev manjše, drži.

Graf 18: Frekvenčna porazdelitev števila prodanih smučarskih kart na Krvavcu glede na pojav megle (januar-marec 2003, 2004)

Figure 18: Frequency distribution of the number of ski tickets sold on Krvavec according to the appearance offog

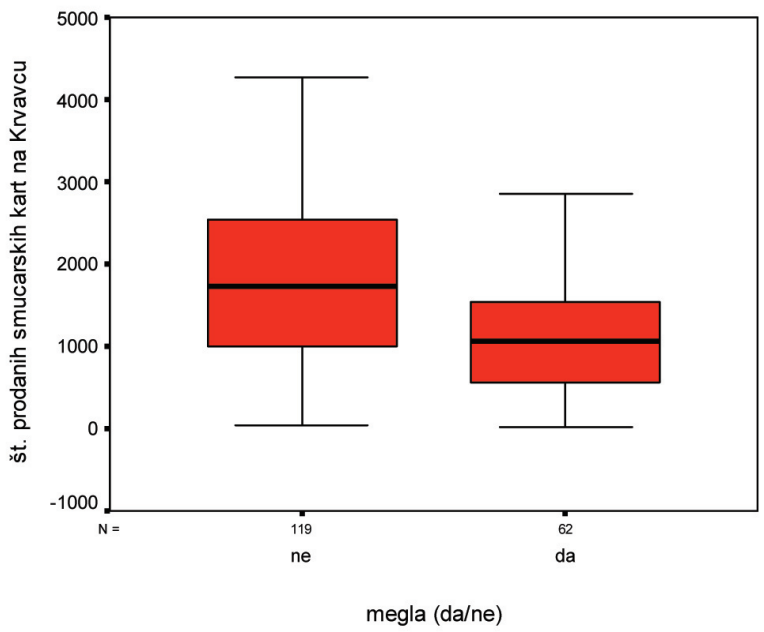

f) Na podlagi opisne statistike lahko ugotovimo, da je bilo število obiskovalcev v primeru suhih dni opazno večje kot v primeru padavinskih dni v primeru Krvavca, saj padavine, četudi v obliki snega, ovirajo smučanje in zmanjšujejo estetske užitke pri smuki. 
Graf 19: Frekvenčna porazdelitev števila prodanih smučarskih kart na Krvavcu glede na tip padavin (januar-marec 2003, 2004)

Figure 19: Frequency distribution of the number of ski tickets soldon Krvavec according to the precipitation type (January-March 2003, 2004)

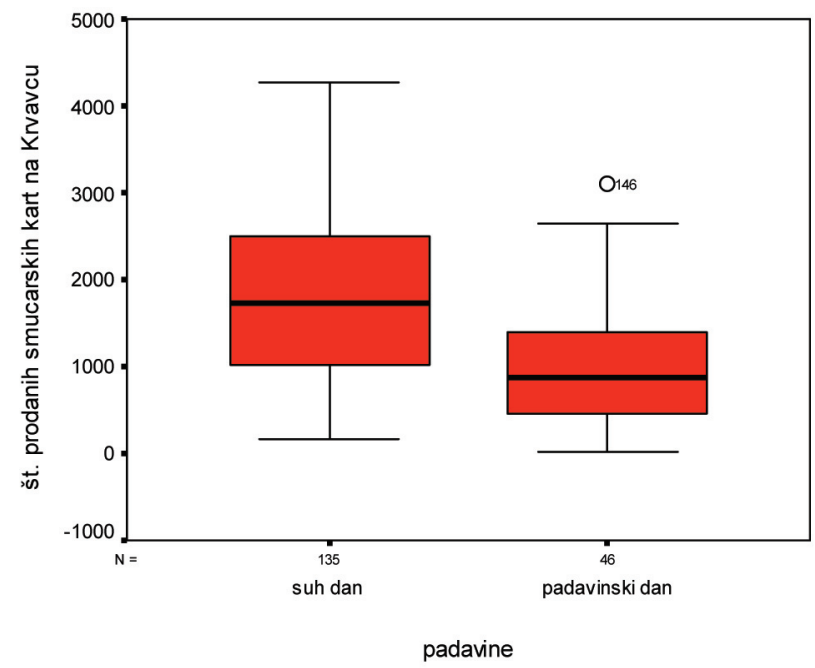

Graf 20: Frekvenčna porazdelitev števila obiskovalcev Logarske doline glede na tip padavin (majseptember 2003, 2004)

Figure 20: Frequency distribution of the number of visitors of the Logarska dolina valley according to the precipitation type (May-September 2003, 2004)

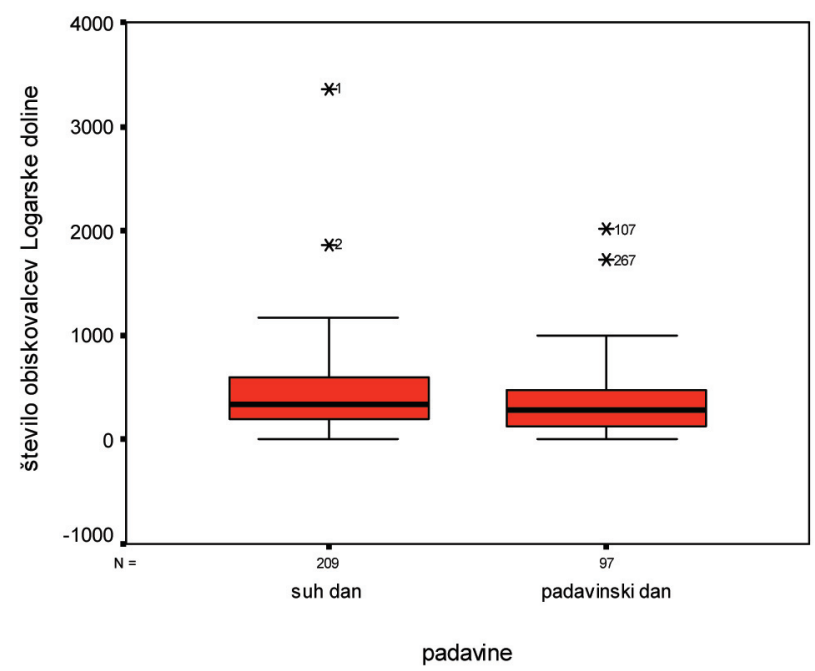


Graf 21: Frekvenčna porazdelitev števila obiskovalcev slapa Savice glede na tip padavin (maj-julij 2002, 2003)

Figure 21: Frequency distribution of the number of visitors of the Savica waterfall according to the precipitation type (May-July 2002, 2003)

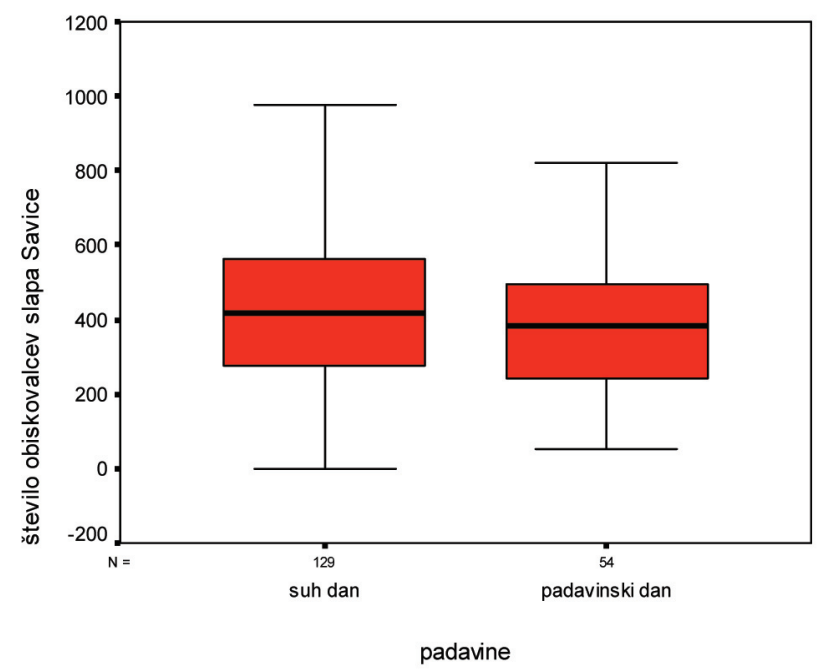

Graf 22: Frekvenčna porazdelitev števila obiskovalcev vpisanih v planinsko knjigo na Veliki planini glede na tip padavin (junij-september 2002, 2003)

Figure 22: Frequency distribution of the number of visitors registered in the mountaineers' book on the Velika planina alp

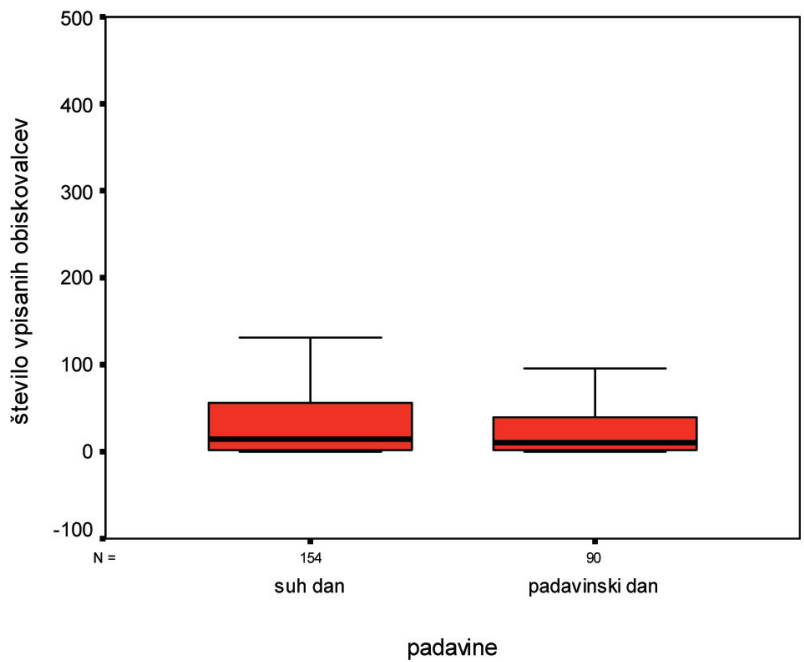


Tudi v primeru Logarske doline, slapa Savice in Velike planine je biloštevilo obiskovalcev ob suhih dnevih večje kot ob deževnih, razlika pa je dosti manj očitna.

Iz grafa 23, ki prikazuje frekvenčno porazdelitev števila obiskovalcev Postojnske jame glede na padavine, je razvidno, da padavine niso imele bistvenega vpliva na število obiskovalcev (razlika med aritmetičnimi sredinami, medianami, zgornjimi in spodnjimi kvartili je skorajda ničelna), kar pomeni, da lahko šesto hipotezo potrdimo.

Graf 23: Frekvenčna porazdelitev števila obiskovalcev Postojnske jame glede na tip padavin (januar-december 2002, 2003)

Figure 23: Frequency distribution of the number of visitors of the Postojnska jama cave according to the precipitation type (january-December 2002, 2003)

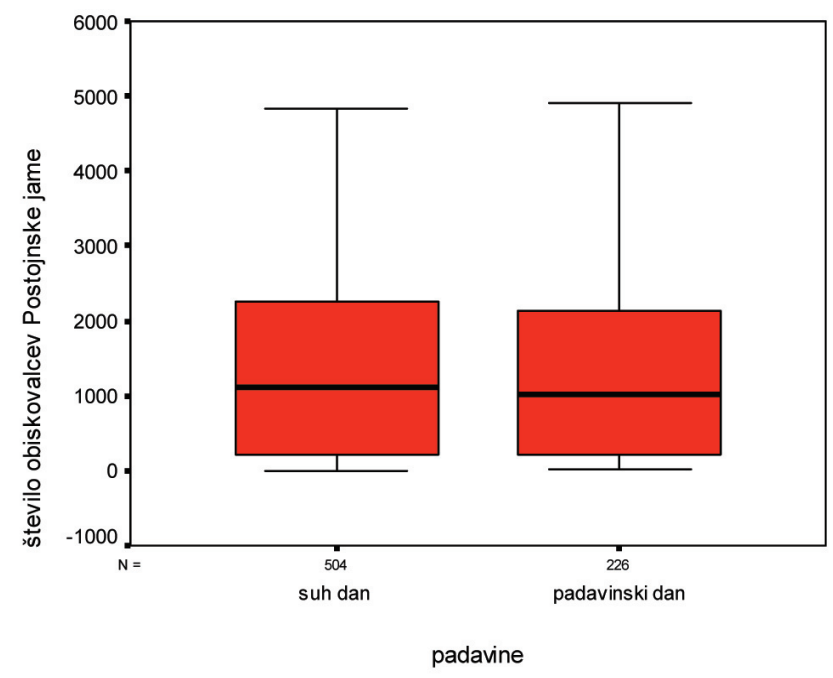

Eden izmed vzrokov zakaj vpliv padavin na število obiskovalcev razen $\mathrm{v}$ primeru Krvavca ni tako očiten je verjetno tudi ta, da se po Wakoniggovi klasifikaciji med padavinske dni uvrščajo tudi tisti dnevi, pri katerih so padavine kratkotrajne, a intenzivne (poletne vročinske plohe in nevihte), vpliv teh padavin na turistični obisk pa je lahko minimalen.

Vsemu navkljub pa so raziskovalci enotnega mnenja, da padavine in oblačno vreme negativno vplivajo na človekovo počutje, saj "slabo" vreme sproža depresivna in "zaspana" čustva, kar zagotovo vpliva na manjši turistični obisk (Xaychaleune, 2003).

g) Za kompleksno neodvisno spremenljivko fiziološki ekvivalent temperature lahko ugotovimo, da se je v Logarski dolini, pri slapu Savica in na Veliki planini število obiskovalcev s povečevanjem občutka toplote povečevalo, kar je verjetno v največji meri povezano z višjimi temperaturami na višku sezone (julija, avgusta). 
Na Krvavcu je bil fiziološki ekvivalent temperature vedno enak (do $\left.4^{\circ} \mathrm{C}\right)$, zaradi česar je v tem primeru o vplivu fiziološkega ekvivalenta temperature nemogoče karkoli reči.

Samo v Postojnski jami se je število obiskovalcev ob rahlo toplem vremenu zmanjšalo, ker pa je numerus takšnih dni le 2, je iz tega nemogoče sklepati, da se s povečevanjem toplotne obremenitve število obiskovalcev zmanjšuje.

Dodati je potrebno, da na nobeni izbrani turistični točki v izbranem obdobju fiziološki ekvivalent ni dosegel vrednosti, ki so za telo tako obremenilne, da bi dejansko lahko negativno vplivale na obisk. Je pa res, da smo izbrali točke, ki ležijo v alpskem svetu; izjema je Postojnska jama, ki je predstavljena zato, ker predstavlja znamenitost v zaprtem prostoru. Iz alpskega sveta nam namreč ni uspelo dobiti podatkov o obiskanosti turističnih točk v zaprtem prostoru.

Kljub izredno vročemu poletju 2003 na izbranih alpskih turističnih točkah temperaturna obremenitev ni bila velika, kar kaže na to, da bi alpski svet v prihodnosti lahko postal nekakšno pribežališče obiskovalcev pred obremenjujočo vročino.

Graf 24: Frekvenčna porazdelitev števila obiskovalcev Logarske doline glede na tip fiziološke obremenitve (maj-september 2003, 2004)

Figure 24: Frequency distribution of the number of visitors of the Logarska dolina valley according to the type of physiologic stress (May-September 2003, 2004)

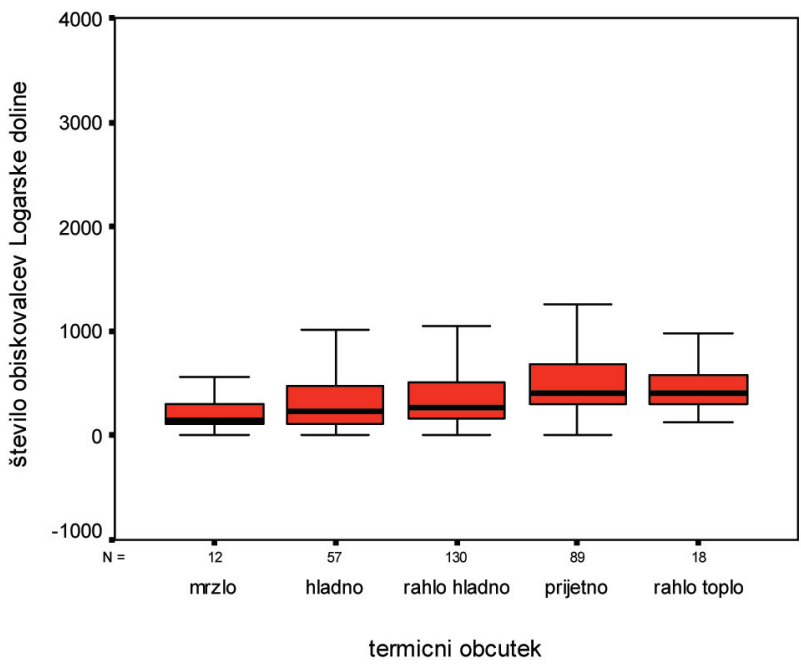


Graf 25: Frekvenčna porazdelitev števila obiskovalcev Postojnske jame glede na tip fiziološke obremenitve (januar-december 2002, 2003)

Figure 25: Frequency distribution of the number of visitors of the Postojnska jama cave according to the type of physiologic stress (January-December 2002, 2003)

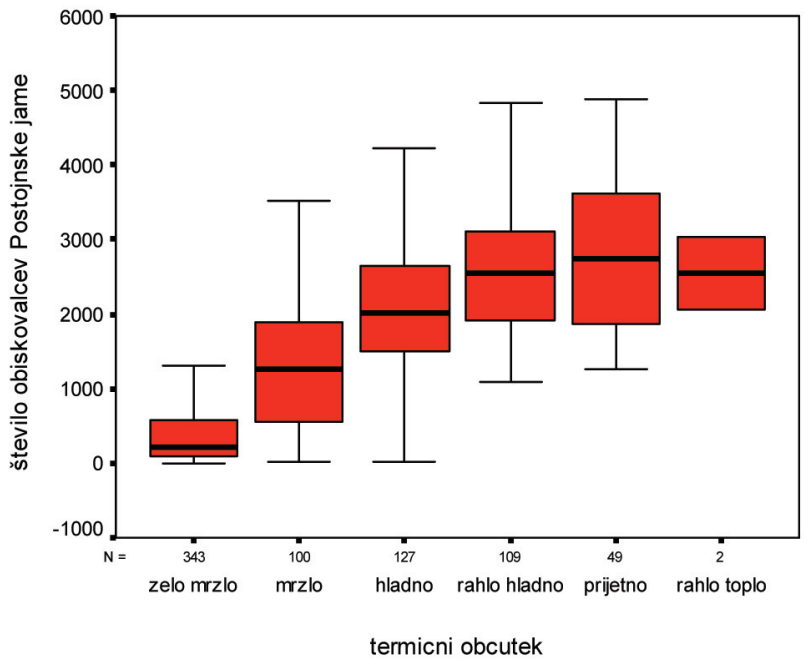

Graf 26: Frekvenčna porazdelitev števila obiskovalcev slapa Savice glede na tip fiziološke obremenitve (maj-julij2002, 2003)

Figure 26: Frequency distribution of the number of visitors of the Savica waterfall according to the type of physiologic stress (May-July 2002, 2003)

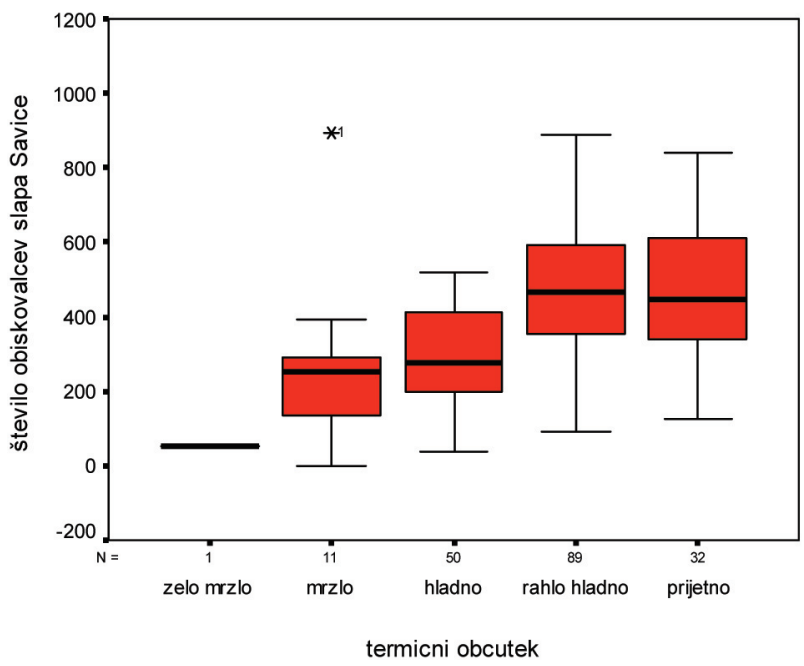


Graf 27: Frekvenčna porazdelitev števila prodanih smučarskih kart na Krvavcu glede na tip fiziološke obremenitve (januar-december 2003, 2004)

Figure 27: Frequency distribution of the number of ski tickets sold on Krvavec according to the type of physiologic stress (January-December 2003, 2004)

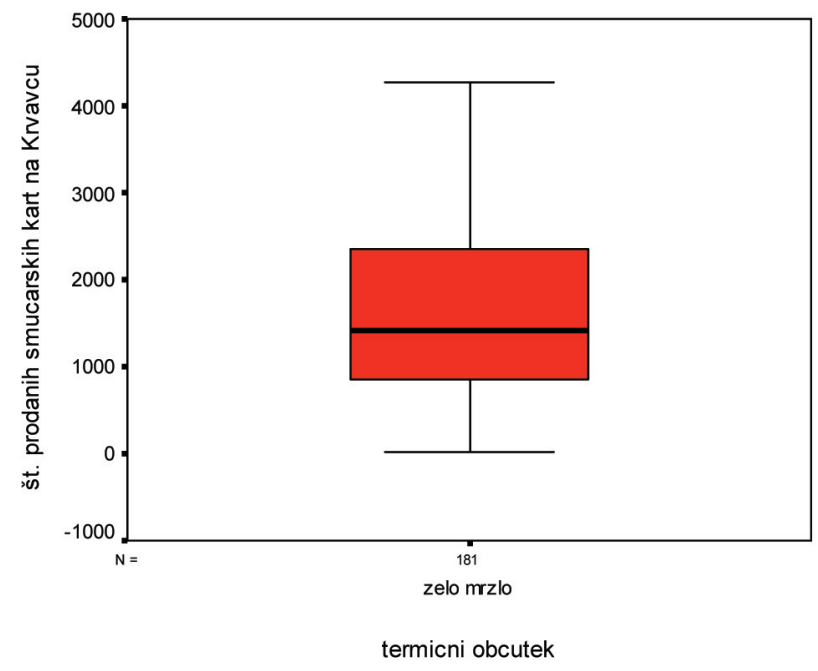

Graf 28: Frekvenčna porazdelitev števila obiskovalcev vpisanih v planinsko knjigo na Veliki planini glede na tip fiziološke obremenitve (junij-september 2002, 2003)

Figure 28: Frequency distribution of the number of visitors inscribed into the mountaineers' book on the Velika planina alp according to the type of physiologic stress (June-September 2002, 2003)

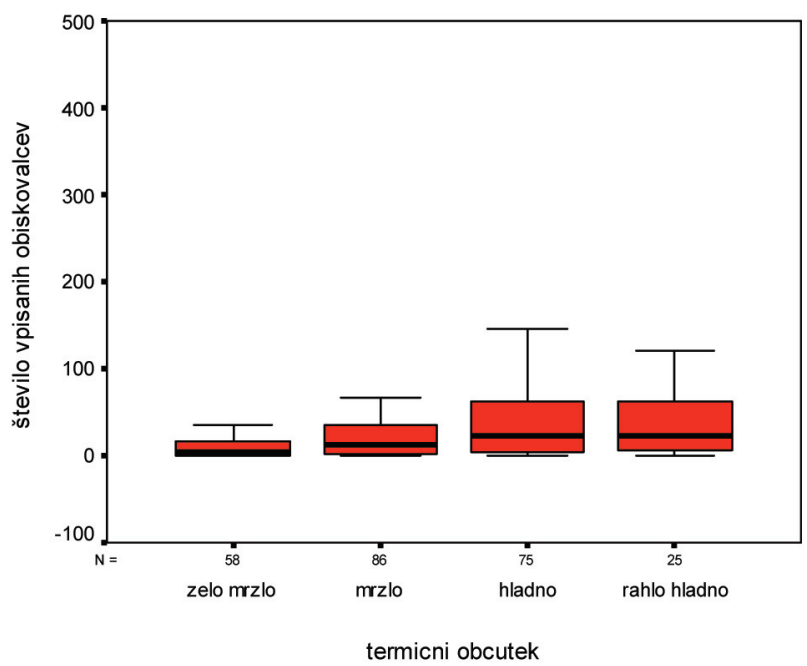




\section{SKLEPI}

Pri ugotavljanju vzorcev povezanosti med vremenskimi parametri, fiziološkim ekvivalentom temperature in številom obiskovalcev izbranih turističnih točk, na podlagi česar smo skušali sklepati o povezanosti med vremenom in turističnim obiskom, je bila prva hipoteza sprejeta na primerih vseh turističnih točk. V vseh primerih je bilo število obiskovalcev ob dela prostih dnevih namreč večje kot ob delovnih dneh ne glede na vreme. Druga hipoteza se je potrdila na primerih vseh turističnih točk razen Krvavca, kjer smo ugotovili, da temperature nimajo pomembnega vpliva na število smučarjev oziroma, da je njihov vpliv minimalen. Tretja pa se je izkazala za popolnoma pravilno le v primeru Krvavca in Logarske doline, delno tudi na primeru Velike planine. V primeru slapa Savice pa je bilo število obiskovalcev največje, ko je bilo vreme oblačno, temu pa so sledili dnevi z jasnim in lepim vremenom. Razlog za nastalo sliko je lahko dejstvo, da je nebo v Bohinju pogosto pokrito z oblaki (če bi vzeli meteorološke podatke za Vogel, bi bilo število oblačnih in turobnih dni še večje), ker pa slap Savica običajno ne predstavlja končni cilj turistov, ampak je samo eden izmed zelo privlačnih postankov, povečana oblačnost obiskovalce očitno ne moti.

Pri Postojnski jami se je četrta hipoteza, ki pravi, da povečana oblačnost nima vpliva na število obiskovalcev v zaprtem prostoru, oziroma, da se s povečano oblačnostjo število obiskovalcev celo poveča, potrdila za obdobje glavne sezone (maj-julij), medtem ko za celo leto ta hipoteza ne drži. Vzrok je v tem, da je največ oblačnih in turobnih dni v času izven glavne sezone, ko je število obiskovalcev že tako ali tako manjše.

Kar se tiče vpliva padavin, smo na podlagi naših podatkov ugotovili, da je bilo število obiskovalcev izbranih turističnih točk v primeru suhih dni opazno večje kot ob padavinskih dneh na Krvavcu, saj padavine, četudi v obliki snega, ovirajo smučanje in zmanjšujejo estetske užitke pri smuki. Tudi v primeru Logarske doline, slapa Savice in Velike planine je bilo število obiskovalcev ob suhih dnevih večje kot ob deževnih, razlika pa je dosti manj očitna. Potrdila se je tudi hipoteza, da padavine ne vplivajo na obisk Postojnske jame.

Hipoteza ki pravi,da se z višanjem fiziološkega ekvivalenta temperature število obiskovalcev povečuje, se je potrdila v primeru vseh turističnih točk razen Krvavca, kjer je bila fiziološka obremenitev vedno enaka. Drugega dela hipoteze ki pravi, da se ob veliki predvsem pa ob ekstremni toplotni obremenitvi število obiskovalcev zopet začne zmanjševati, pa na podlagi naših podatkov ni bilo mogoče ne potrditi ne ovreči, saj toplotna obremenitev ni bila nikoli tako velika.

Sodeč po rezultatih raziskave naj bi na obisk Logarske doline, ki je ena izmed najlepših alpskih dolin v Sloveniji, vplivale temperature, oblačnost, padavine in fiziološki ekvivalent temperature, na obisk slapa Savice, ki je najbolj obiskan slovenski slap, pa temperature in padavine. Na obisk smučišča na Krvavcu, ki ga zaradi pomanjkanja prenočišč in zaradi bližine populacijski osi obiskujejo predvsem vsakodnevni obiskovalci, po pričakovanjih vplivajo predvsem vremenski parametri, ki otežujejo smučanje in zmanjšujejo estetske užitke ob smuki. To so oblačnost, megla in pa padavine. Na obisk Velike planine, ki je ena izmed najbolj priljubljenih planinskih postojank v Sloveniji, pa vplivajo temperature, oblačnost, padavine in fiziološki ekvivalent temperature, povezanost pa ni tako očitna kot bi za planinsko postojanko pričakovali. Vzrok za to je v naši ne najbolj posrečeni izbiri lokacije. Na Veliko planino se 
namreč lahko pride tudi z nihalko, s čimer se vpliv vremena na obisk močno zmanjša, zaradi lažje dostopnosti pa je tudi doslednost pri vpisovanju v planinsko knjigo manjša. Zato za Veliko planino formula: število obiskovalcev $=3 *$ število obiskovalcev vpisanih v planinsko knjigo ne drži. Izven ležeče vrednosti in ekstremne vrednosti v grafih pa tako verjetno prikazujejo dneve, ob katerih so na Veliko planino prišle večje organizirane skupine izletnikov oziroma planincev.

Na obisk Postojnske jame, ki predstavlja turistično najbolj privlačno znamenitost $\mathrm{V}$ Sloveniji v zaprtem prostoru, vreme nima večjega vpliva, saj je obisk odvisen le od temperatur in fiziološkega ekvivalenta temperature. Poleg tega je Postojna tako imenovan tranziten turistični kraj, saj se nahaja na poti proti morju in tako se mnogi turisti, ki potujejo na obalo, odločijo še za postanek v Postojni in obisk Postojnske jame. Ugotovitve o svojevrstnem značaju Postojne potrjuje tudi Paternost (2004), ki skrbi za oglaševanje Postojnske jame. Ugotavlja namreč, da poleti, na višku turistične sezone, ogromno turistov obišče jamo takrat, ko je na slovenski obali ali pa v hrvaški Istri dež, saj turisti takšne dni, ki niso primerni za kopanje in sončenje, izkoristijo za obisk turističnih zanimivosti, katerih obisk ni vezan na lepo vreme. Pomladi in jeseni, ko so temperature za kopanje prenizke, pa je obisk Postojnske jame največji takrat, ko je vreme "'lepo" (jasno, suho), še posebno če je takšno ob koncu tedna. To pa je potrdila tudi naša analiza, ki je vključila podatke za celo leto.

Pri naši analizi pa se postavlja vprašanje, kako zanesljivo lahko govorimo o povezanosti med posameznimi vremenskimi parametri in turističnim obiskom, saj se v enem dnevu lahko zvrsti več vremenskih situacij. Tako npr. velika količina padavin ne vpliva nujno na turistični obisk, saj lahko le-te padejo v obliki kratkotrajne popoldanske plohe ali nevihte z intenzivnimi, čeprav kratkotrajnimi padavinami. Pri naslednjih raziskavah bi bilo tako verjetno smiselno definirati količino padavin $\mathrm{v}$ posameznem dnevu glede na trajanje in porazdelitev preko dneva.

Sklepamo lahko, da po rezultatih naše raziskave temperature, oblačnost, padavine, fiziološki ekvivalent temperature, v primeru smučišč pa tudi megla, vplivajo na število turistov v krajih, kjer se odvijajo aktivnosti na prostem, število obiskovalcev zanimivosti v zaprtem prostoru pa je vremensko precej manj občutljivo. Na podlagi tega bi lahko predvidevali, v kateri smeri bi se število obiskovalcev na posameznih območjih gibalo ob podnebnih spremembah (zvišanje temperatur, zvišanje/znižanje količine padavin, povečanje/zmanjšanje oblačnosti).

Menim, da je potrebno v sklepu izpostaviti, da deskriptivne statistike niso namenjene preverjanju domnev, ampak nam dajo le boljši vpogled v značaj spremenljivk. Za preverjanje domnev bi bilo namreč potrebno uporabiti drugo metodo.

Nenazadnje bi rada dodala, da je nekatere probleme, še posebno takšne, ki vključujejo močan psihološki faktor, mogoče bolj učinkovito razlagati s pomočjo kvalitativnih metod. Takšno je tudi vprašanje povezanosti med vremenom, podnebjem in turističnim obiskom, zaradi česar menim, da bi raziskavo lahko dopolnili še z uporabo kvalitativnih metod, saj bi tako dobili vpogled v posameznikovo dojemanje vremena, njegovega (ne)ugodnega vpliva na počutje in doživljanje sveta ter posameznikovo reagiranje na njegovo spremenljivost. 


\section{Viri in literatura}

Abegg, B., 1996. Klimaänderung und Tourismus: Klimafolgenforschung am Beispiel des Wintertourismus in den Schweizer Alpen. Zürich, Hochschulverlag AG an der ETH Zürich, 222 str.

Brandenburg, C., 2001. Erfassung und Modellierung von Besuchsfrequenzen in Erholungsund Schutzgebieten. Anwendungsbeispiel Nationalpark Donau-Auen, Teilgebiet Lobau. Wien, Institut für Freiraumgestaltung und Landschaftspflege, Universität für Bodenkultur, 166 str.

Dnevni podatki za vremenske parametre v obdobju junij-september 2002/2003 za meteorološke postaje Krvavec, Lesce in Postojna in 2003/2004 za meteorološki postaji Krvavec ter Velenje. Arhiv ARSO za leta 2003, 2003 in 2004.

Houghton, J.T., (et al.), 2001. Climate change 2001: The scientific basis. Cambridge, Cambridge University Press, 752 str.

URL: http:/www.grida.no/climate/ipcc_tar/wg1/index.htm (citirano 15.6.2004).

Matzarakis, A., Rutz, F., Mayer, H., 2000. Modelling the Mean Radiation Temperature and Thermal Indices in Urban Structures. Universität Freiburg, Meteorologisches Institut.

URL: http://www.mif.uni-freiburg.de/rayman/index.htm (citirano 28.7.2005).

Paternost, S., 2004. Vpliv vremena na obisk Postojnske jame. Ljubljana. (telefonski razgovor, 5.2.2004).

Perry, A., 2003. Impacts of climate change on tourism in the Mediterranean: adaptive responses. In: Climate Change in the Mediterranean: Socio-economic Perspectives of Impacts, Vulnerability and Adaptation. Cornwal, MPG Books Ltd, 279-289.

Podatki o dnevnem številu obiskovalcev Logarske doline v letih 2003 in 2004. Arhiv Lokalne turistične organizacije Logarska dolina.

Podatki o dnevnem številu obiskovalcev Postojnske jame v letih 2002 in 2003. Arhiv Postojnska jama turizem d.d.

Podatki o dnevnem številu obiskovalcev slapa Savice v obdobju maj-julij 2002 in 2003. Arhiv Lokalne turistične organizacije Bohinj.

Podatki o dnevnem številu obiskovalcev Velike planine vpisanih v planinsko knjigo v obdobju junij-september 2002 in 2003. Arhiv Planinskega društva Domžale.

Podatki o dnevnem številu prodanih smučarskih kart na smučišču Krvavec v obdobjih januarmarec 2003, 2004. Arhiv RTC Krvavec.

Rakovec, J., Vrhovec, T., 1998. Osnove meteorologije za naravoslovce in tehnike. Ljubljana, Društvo matematikov, fizikov in astronomov Slovenije, 318 str.

Statistične informacije: gostinstvo in turizem 2003. Ljubljana, Statistični urad Republike Slovenije, 2004.

Statistični urad Republike Slovenije. Turizem, december 2005 (Prva objava). 2003.

URL: http://www.stat.si/novice_poglej.asp? ID913 (citirano 23.5.2006)

Zajec, J. Osebni razgovor. Ljubljana, 23.1.2004.

Xaychaleune, T., 2003. Weather's Influence on Travel and Tourism. Commission - Climate, Tourism, and Recreation.

URL: http://www.mif.uni-freiburg.de/isb/studygroup.htm (citirano 28.8.2004). 


\section{THE CONNECTION BETWEEN THE WEATHER AND THE VISITS OF SELECTED TOURIST POINTS IN SLOVENIA}

\section{Summary}

Tourism and recreation are strongly connected with the weather, the climate and its changes. Extreme weather situations in the recent years have triggered various researches on the possible influences of the predicted climate changes on different spheres of human life, also on tourism and recreation. But since this economic sector is influenced by many different factors, its responses to climate changes are very difficult to predict. One of the most important factors influencing tourism and recreation is definitely the weather because it influences the short-term variability of the number of tourists and daily visitors (Brandenburg, 2001). Therefore, in this research we used data on the daily number of visitors of selected different types of tourist points in Slovenia to find out what the connection between the weather and the number of visitors is actually like. Furthermore, their responses can give us an insight into the possible influences that climate changes, through changed weather patterns, might have on the variation of the number of tourists and daily visitors.

In the research we used the data on the daily weather at corresponding meteorological stations (Velenje, Postojna, Lesce and Krvavec) in the periods for which it was possible to get the data on the daily number of visitors of the Logarska dolina valley, the Postojnska jama cave, the Savica waterfall, the Krvavec ski center (here the number of the sold ski tickets was considered) and the Velika planina alp (here the number of visitors registered into the mountaineers' book was counted). In order to ascertain the connection between the weather parameters and the number of visitors of individual tourist points, the data on the days, the weather parameters and the physiologic equivalent of temperature were classified and then descriptive statistics was used to show what the frequency distribution of the number of visitors in individual classes is like. On the basis of this we tried to find out if the patterns show any regularities in the appearance of the number of visitors of selected tourist points according to individual weather parameters.

The results of the research show that the visit of the Logarska dolina valley, which is one of the most beautiful alpine valleys in Slovenia, is influenced by temperature, cloudiness, precipitation and physiologic equivalent of temperature; and the visits of the Savica waterfall, which is the most visited Slovene waterfall, are influenced by temperature and precipitation. The visits of the ski centre on Krvavec, which is due to the lack of accommodation facilities and due to the nearness of the population axis, visited mostly by everyday visitors, are, as expected, influenced especially by the weather parameters which hinder skiing and lessen aesthetic pleasures at skiing. These are cloudiness, fog and precipitation. The visits of the Velika planina alp, which is one of the most popular mountain points in Slovenia, are influenced by temperatures, cloudiness, precipitation and physiologic equivalent of temperature but the connection is not as big as it would be expected for a mountain point. The reason for this lies in our not very good choice of location. Namely, the Velika planina alp is accessible also by a gondola with which the influence of the weather on the visit significantly decreases, and as a result of easier accessibility the visitors are less consistent at registering into the mountaineers' book. 
The visit of the Postojnska jama cave, which represents the most attractive tourist point in Slovenia in a closed space, is not importantly influenced by the weather because the visits depend only on temperatures and the physiologic equivalent of temperature.

It can be concluded that, according to the results of our research, the number of tourists in places where activities take place in the open air, is besides the day of the week influenced by temperatures, cloudiness, precipitation, physiologic equivalent of temperature, and in the case of ski slopes also the fog, whereas the number of visitors of the attractions in a closed space/area is much less weather sensitive. On the basis of this it could be forecasted in which direction the number of visitors in individual areas would move in case of the predicted climate changes (increase of temperatures, increase/decrease of precipitation quantity, increase/ decrease of cloudiness). 